\title{
Treatment of Leather with Synthetic Resins ${ }^{1}$
}

\author{
By Rene Oehler and Timothy J. Kilduff
}

\begin{abstract}
Laboratory methods have been developed for treating leather with snythetic resins. The first method of treatment may be accomplished by immersing the leather specimens in monomer and subsequently polymerizing in situ; the second method consists of immersing the specimens in polymer solutions; and the third method involves immersion in a solution of partially polymerized liquid resin, which is further polymerized in the leather itself. The last method was developed in cooperation with the Thiokol Corporation, using Thiokol LP-2.

Abrasion resistance of vegetable-tanned crust leather treated with $n$-butyl methacrylate, polymerized in situ, is increased by approximately 75 percent, as measured on the National Bureau of Standards abrasion machine. Treatment with Thiokol LP-2 increased abrasion resistance by approximately 30 percent. However, treatment of vegetable-tanned crust leather with polybutyl methacrylate solution-polymer resulted in no improvement in abrasion resistance. One-half-hour water absorption data show a reduction of one-tenth to one-third that of untreated leather, depending upon the kind of treatment and leather.

By proper choice of monomers and polymerization conditions, stiffness may be controlled to meet the needs of different types of leather.

Water vapor permeability of shoe upper leather is reduced 60 percent, but is still considered ample for foot comfort.
\end{abstract}

\section{Introduction}

Preliminary research, conducted at the National Bureau of Standards in 1944, showed that certain acrylate monomers might be successfully polymerized in leather within leather. However, it was not possible to resume work on this project until 1946. Because of the excellent penetration of monomers into leather and the promise of successful polymerization in situ, to give resins of suitable molecular weights, it was hoped that the wear resistance of sole leather and the water resistance of sole upper leather could be improved.

This paper presents the first results of a systematic study of the general problem of impregnating leather with resins and plastics.

Earlier work has resulted in many well-known finishing agents or coating materials for different types of leather. However, very little is known

\footnotetext{
1 This report is made as a part of the Leather Research Program sponsored by the Research and Development Branch, Military Planning Division, of the Office of the Quartermaster General, United States Army. This program is under the Advisory Direction of the National Research Council.
}

concerning their use as impregnants for leather. The chief reason for this lack of information is that ordinary, commercial resins do not penetrate leather to any considerable extent. This lack of penetration is borne out in a paper by Niedercorm and Thayer $[1],{ }^{2}$ who studied 25 different resins of several types. They found that the maximum resin content of treated sole leather was only 6.9 percent, which resulted in only a slight improvement in abrasion resistance. In fact, they found that an oil treatment resulted in a greater and more consistent improvement than did the resin treatments.

Chadwick [2] reviewed the whole field of plastics as applied to leather. He proposed, among other things, that since polyisobutylene is compatible with certain waxes and oils, it might advantageously replace part of the waxes and oils normally used in sole leather; he also suggested that certain thermosetting resins that were only partially

2 Figures in brackets indicate the literature references at the end of this paper. 
polymerized might be further cured by heat after impregnation; he suggested, too, that properly plasticized thermoplastic resins, such as polyvinyl chloride, polyvinyl chloride-acetate copolymer, and polyvinylidene chloride should be especially useful for sole leather because of their outstanding abrasion resistance.

Virtue [3] has reported 50-percent improvement in wear resistance by impregnating finished taps with 8 to 12 percent of maleic anhydride modified alkyd, or modified phenolic resin.

The wide differences in type of resins used and suggested by the above authors present the problem of selecting suitable resins with which to work. The salient points considered in making selections are discussed in the next section.

\section{Selection and Properties of Resins}

The resins selected to begin this study were the acrylates and methacrylates, because of ready availability, rather wide range of properties within the series of esters and relative ease of polymerization. The resin selected should have properties which will improve the wear of leather without seriously detracting from the desirable characteristics of leather. For example, a resin to be used for sole leather should have a greater abrasion resistance and may be more viscous than a resin to be used for shoe upper leather. Specific characteristics to be considered in selecting a resin are: proper flexibility of the treated leather, toughness, high abrasion resistance, high extensibility, low water absorption, and low water penetration.

TABLE 1. Properties of methacrylate ester polymers

\begin{tabular}{|c|c|c|c|c|c|}
\hline Properties & $\begin{array}{l}\text { Me- } \\
\text { thyl }\end{array}$ & Ethyl & $\begin{array}{l}\text { Nor- } \\
\text { mal } \\
\text { pro- } \\
\text { pyl }\end{array}$ & $\begin{array}{l}\text { Nor- } \\
\text { mal } \\
\text { butyl }\end{array}$ & $\begin{array}{l}\text { Iso- } \\
\text { butyl }\end{array}$ \\
\hline Density at $25^{\circ} \mathrm{C} \ldots \ldots$ & 1. 19 & 1. 11 & 1.06 & 1.05 & 1.02 \\
\hline Hardness (Pfund) at $25^{\circ} \mathrm{C} \ldots$ & 220 & 141 & 100 & 1 & 210 \\
\hline Thermal yield point, ${ }^{\circ} \mathrm{C}$ & 125 & 65 & 38 & 30 & 70 \\
\hline Tensil strength, $\mathrm{lb} / \mathrm{in} .^{2} \ldots \ldots$ & 9,000 & 5,000 & 4,000 & 1,000 & 3,400 \\
\hline Impact strength (Dynstat), kg-cm/cm.2 & 10.5 & 7.1 & 6.5 & 11.5 & 1. 6 \\
\hline Refractive index & 1. 490 & 1.485 & 1. 484 & 1: 483 & 1. 477 \\
\hline $\begin{array}{l}\text { Extensibility, 5-mil films (percentage } \\
\text { at break) }\end{array}$ & 4 & 7 & 5 & 230 & 2 \\
\hline $\begin{array}{l}\text { Toughness, area under load-elongation } \\
\text { curve, expressed in arbitrary units.. }\end{array}$ & 98 & 174 & 76 & 1,000 & 23 \\
\hline
\end{tabular}

The principal properties of the common polymethacrylates have been reported, as shown in table 1, by Strain, et al. [4]. This table shows that polybutyl methacrylate should be the most satisfactory of the group for treating sole leather. Of course, no single resin or any other material can have all the desirable properties that may be enumerated. Consequently, compromises must be made to obtain the most desirable properties. These compromises can best be achieved by the addition of plasticizers or by polymerizing two or more monomers to form copolymers or interpolymers with properties intermediate between those of the separately polymerized monomers.

\section{Methods of Treating Leathers}

The three methods used for impregnating leather with resins are immersion of leather in monomer and subsequent polymerization in situ; immersion in polymer solutions followed by evaporation of the solvent; immersion in partially polymerized resin followed by varying degrees of cure, depending upon the desired results. These methods have been studied and will be discussed one at a time.

\section{Immersion in Monomer Followed by Polymeriza- tion in situ}

This method of impregnating leather with resins essentially consists in immersing the weighed leather specimens in a monomer containing benzoyl or lauroyl peroxide catalyst for 15 minutes, wiping off excess solution, reweighing, transferring to a suitable bomb or closed system, heating overnight at a given temperature, evaporating the excess monomer, and weighing again to determine the amount of resin. Several variations were tried in the type of leather treated, the kind and amount of catalyst used, the temperature and time of heating, the different monomers or combinations thereof, the use of oils or other solvents with monomers, the use of liquid monomer (without catalyst) in the polymerization chamber, the relative size of polymerization chamber, and different materials for polymerization chambers.

Preliminary experiments disclosed no consistent relationship between the amount of resin in the treated sole leather and different catalyst concentrations, different vegetable tannages, chrometanned specimens, and different oils used as diluents or plasticizers, or both. However, vegetabletanned crust leather does have the advantage of large pore size and a large void space or capacity to absorb monomer. A temperature range of $70^{\circ}$ to $80^{\circ} \mathrm{C}$ was regarded as about the maximum 
polymerization temperature that could be used without damaging vegetable-tanned crust leather. Accordingly, most of the data presented are concerned with vegetable-tanned crust leather in which polymerization was carried out at $70^{\circ} \mathrm{C}$.

Table 2 shows that the mean resin content obtained in the leather specimens decreased as the volume of the polymerization chamber increased from 19 to $54 \mathrm{ml}$. For chambers larger than $36 \mathrm{ml}$, the resulting resin content falls off rapidly, and all chambers larger than $54 \mathrm{ml}$ are sufficiently large to give more or less uniformly low results. These low results may be due to the evaporation of monomer from the leather, or to the inhibiting action of oxygen, which has been reported by Barnes [5], Heuck [6], and Kolthoff [7]. These factors will, of course, be reduced if the ratio of specimen volume to total volume is nearly 1. Another way of reducing evaporation from the leather is to add liquid monomer to the polymerization chamber. Both ways of improvement will be presented.

Figure 1 clearly shows the effects of adding liquid monomer to the polymerization chamber.
In both groups of data, the points scatter quite uniformly about their respective averages. It should be noted that both the average and the run-to-run variation are considerably higher in the case of added monomer. However, the variability within runs is quite uniform and the same for both sets of data; only two points fall outside reasonable range limits.

TABLE 2. Results of in-situ polymerization of ethyl acrylate in vegetable-tanned crust leather heated at $70^{\circ} C$ for 16 hours

(Composition of impregnant: ethyl-acrylate-neatsfoot oil 50:50, with 5-percent benzoyl peroxide catalyst)

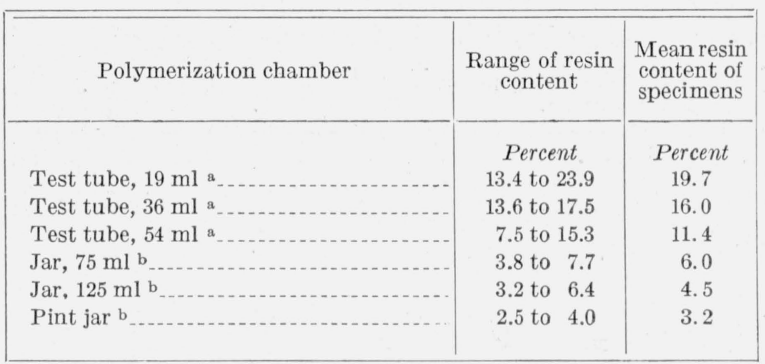

a Single $1 / 2$ - by 3 -in. specimens in each of three tubes.

b Three 1/2- by 3 -in. specimens in each jar.

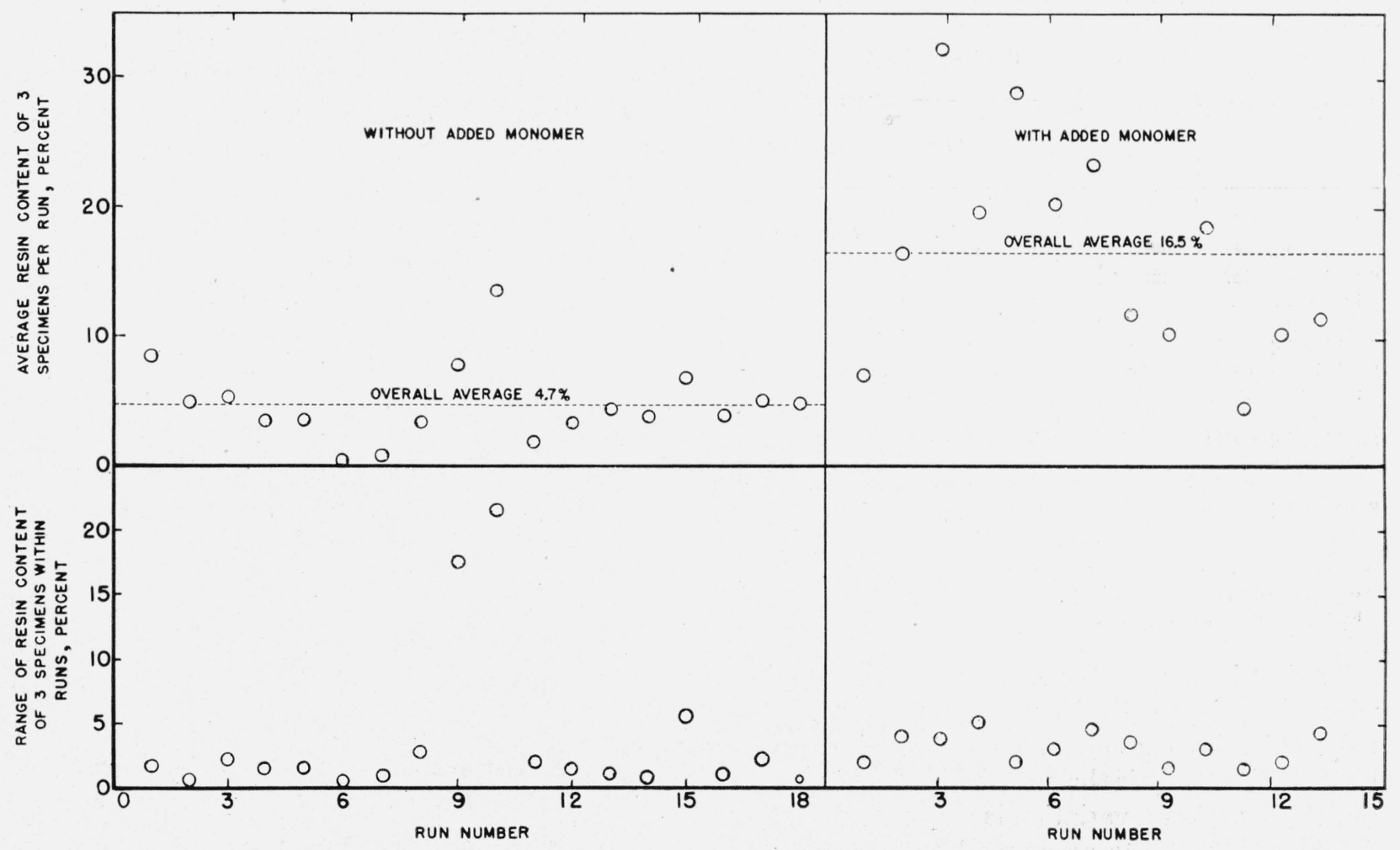

FIGURE 1. Effect of liquid monomer in polymerization chamber on in situ polymerization.

Each point represents one run consisting of three specimens, 1 by 3 in., of vegetable-tanned crust leather impregnated with ethyl acrylate-neatsfoot oil, 50:50, and 5-percent benzoyl peroxide, heated in pint jars for 16 hours at $70^{\circ} \mathrm{C}$. 
Several attempts were made to reduce evaporation of monomer from the leather by using sand as a filler for the excess volume in the polymerization chambers. The amount of resin obtained in the leather specimens varied widely from run to run and from specimen to specimen within runs.

Table 3 shows the inconsistent results obtained when a large steel bomb is used to accommodate full-sized soles. These variations are typical and were repeated several more times than shown in the table. Sometimes nearly all the liquid monomer had polymerized, whereas hardly any polymerization occurred within the leather itself. At other times practically all the liquid monomer was recovered with almost no change in weight of the leather specimens during the heating period. The fact that liquid monomer remained in the polymerization chamber apparently precludes any possibility of a pressure phenomenon influencing the polymerization.

TABLE 3. Results of in-situ polymerization of ethyl acrylate in vegetable-tanned crust leather heated at $70^{\circ} \mathrm{C}$ (except as noted) for $16 \mathrm{hr}$

[Composition of impregnant, 50:50 ethyl acrylate and neatsfoot oil]

\begin{tabular}{|c|c|c|c|c|c|}
\hline \multirow{2}{*}{ Polymerization chamber } & \multirow{2}{*}{$\begin{array}{l}\text { Cata- } \\
\text { lyst } \\
\text { con- } \\
\text { centra- } \\
\text { tion }\end{array}$} & \multicolumn{2}{|c|}{$\begin{array}{l}\text { Specimens } \\
\text { treated }\end{array}$} & \multirow{2}{*}{$\begin{array}{l}\text { Range of } \\
\text { resin content }\end{array}$} & \multirow{2}{*}{$\begin{array}{l}\text { Mean } \\
\text { resin } \\
\text { con- } \\
\text { tent } \\
\text { of } \\
\text { speci- } \\
\text { mens }\end{array}$} \\
\hline & & $\begin{array}{c}\text { Num- } \\
\text { ber }\end{array}$ & Size & & \\
\hline $\begin{array}{l}\text { Steel bomb ( } 8 \text { in. in diameter } \\
\text { by } 14 \text { in. long). }\end{array}$ & $\begin{array}{l}\text { Per- } \\
\text { cent }\end{array}$ & $\begin{array}{l}3 \\
4 \\
6 \\
7\end{array}$ & $\left\{\begin{array}{c}\text { in. } \\
2 \text { by } 6 \\
\text { taps. } \\
2 \text { by } 6 \\
\text { taps. }\end{array}\right.$ & $\left\{\begin{array}{c}\text { Percent } \\
3.2 \text { to } 16.4 \ldots \\
5.5 \text { to } 24.2 \ldots\end{array}\right.$ & $\begin{array}{r}\begin{array}{l}\text { Per- } \\
\text { cent }\end{array} \\
12.0\end{array}$ \\
\hline Steel bomb $+30 \mathrm{ml}$ monomer a & 5 & 8 & 2 by 4 & 2.8 to $19.4 \ldots$ & 15.4 \\
\hline \multirow[t]{2}{*}{$\begin{array}{l}\text { Steel bomb (preheated) }+30 \\
\text { ml monomer. }{ }^{\mathrm{a}}\end{array}$} & 5 & 6 & 2 by 4 & 9.7 to $19.8 \ldots$ & 13. 9 \\
\hline & 2 & 4 & 2 by 4 & 1.2 to $2.5 \ldots$ & 1. 7 \\
\hline \multirow[t]{3}{*}{ Steel bomb $+30 \mathrm{ml}$ monomer ${ }^{\mathrm{b}}$ - } & 4 & 4 & 2 by 4 & 3.8 to $11.8 \ldots$ & 7. 0 \\
\hline & 6 & 4 & 2 by 4 & 12.8 to $25.3 \ldots$ & 17. 4 \\
\hline & 3 & 4 & 2 by 4 & 3.8 to $5.0 \ldots$ & 4.5 \\
\hline \multirow[t]{2}{*}{ Steel bomb $+30 \mathrm{ml}$ monomer ${ }^{\mathrm{b}}$} & 6 & 4 & 2 by 4 & 0.8 to $5.3 \ldots$ & 4. 6 \\
\hline & 12 & 4 & 2 by 4 & 3.6 to $15.2 \ldots$ & 9.1 \\
\hline
\end{tabular}

a Polymerized overnight at $100^{\circ} \mathrm{C}$.

b All 12 specimens were in chamber simultaneously.

Table 4 illustrates the excellent results obtained when there is practically no excess volume in the polymerization chamber over that required for the leather. Not only is the mean resin content higher, but the run-to-run variation is very much reduced. A larger chamber to accommodate full soles with a minimum of excess volume is being built to investigate this avenue of approach further. Table
4 also indicates that a temperature of $50^{\circ} \mathrm{C}$. is sufficient to secure consistent results of about half the resin content obtained at $70^{\circ} \mathrm{C}$. These lower results are probably sufficient for sole leather, as will be pointed out below.

TABLE 4. Polymerization in situ, using 2-in. disks of vegetable-tanned crust leather, 5-percent lauroyl peroxide catalyst, and 2-in. pipe fittings as the polymerization chamber

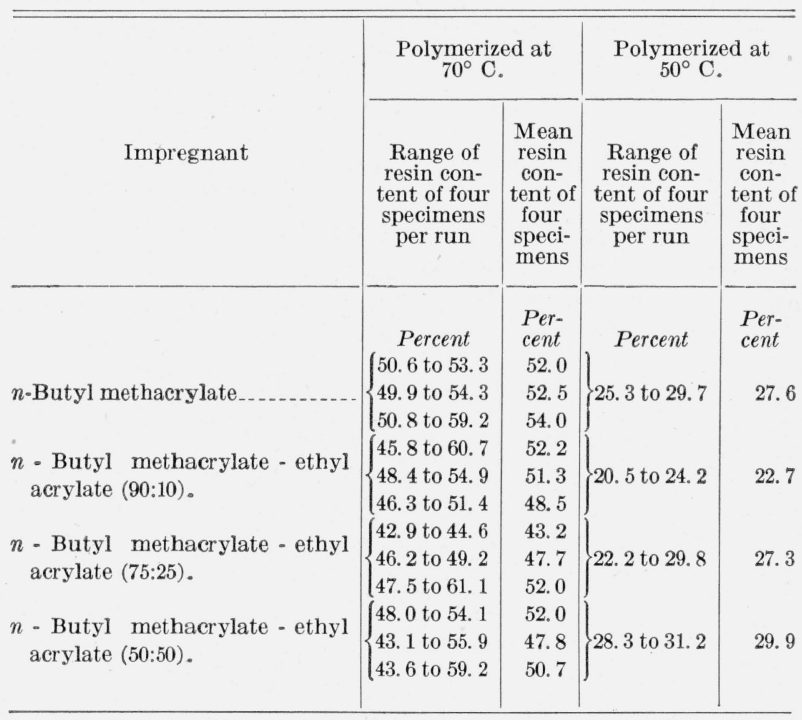

Additional data show that oils and diluents alone or together have varying effects on in situ polymerizations. Neatsfoot and castor oil do not appear to have an appreciable effect on the extent of polymerization, but they do act as plasticizers and diluents. Polyethyl acrylate by itself shrinks and distorts the leather specimens. However, when it is copolymerized with $n$-butyl methacrylate, or when used with about 10 percent of oil, no shrinkage or distortion results. Methyl ethyl ketone is satisfactory as a diluent, but Stoddard solvent, perchloroethylene, Marcol JX (a waterwhite mineral oil), carbon tetrachloride, dioxane, ethanol, and ethyl acetate inhibit practically all polymerization.

Test data on treated leather will follow in section IV, which compares other treatments, as well as this one, with untreated leather.

\section{Immersion in Polymer Solutions}

Leather may be impregnated with resins by means of certain polymer solutions. In order to use polymer solutions, the molecular weight of the resin and the viscosity of the solution must be 
sufficiently low to obtain penetration into the lea ther. Impregnating solutions for this purpose $\mathrm{m}$ ay be obtained by making solution-polymers in a solvent, especially for use in leather, or by using solutions of resins, which are known to have low molecular weight.

\section{(a) Specially Prepared Solution-Polymers}

The preparation of special solution-polymers is quite easy, and by using different dilutions of the prepared resin, any desired resin content up to 50 percent has been obtained. Briefly, the method of preparing these solution-polymers consists in placing a solution of one or more monomers with lauroyl peroxide catalyst in a flask, and refluxing until the desired resin solids are obtained. The extent of penetration depends upon the nature of the monomer used, the molecular weight of the polymer, the viscosity, and the solids content of the resin solutions. For sole leather a resin is desired that will add materially to abrasion resistance (requires moderately high molecular weight) and yet penetration of the resin must be secured (requires low molecular weight or viscosity). Hence, a compromise between high and low molecular weight resins must be found. Variations were made in a number of factors that influence molecular weight, such as solvents, temperature, catalyst concentration, monomer concentration in solution, etc. The prepared resin solutions were used by immersing the leather specimens for $1 / 2$ hour, wiping off the excess solution, and evaporating the solvent at $80^{\circ} \mathrm{C}$ for 4 to 6 hours.

Typical changes in polymerization conditions and resultant effects on the amount of resin obtained in treated vegetable-tanned crust leather are shown in table 5 . The different reflux periods for run 1 show that resin solids or polymerization yield increases with prolonged heating. As the solids increase, the viscosity also increases. Consequently, run 1 shows that the mean resin contents of treated specimens corresponding to the different reflux periods are all approximately the same. The last column of table 5 lists the ratio of resin found in the treated leather to the resin calculated. The calculated resin is the product of the solution pick-up and resin solids in solution. Ratio values of 95 percent and higher indicate that the resins are sufficiently low in molecular weight and viscosity for rather complete absorption. Ratios in excess of 100 percent are probably due to the difficulty of removing the solvent from the resin in the interior of the treated leather. If one considers that the absorption is complete in all four parts of run 1 , it would be expected that the resin content would increase with increasing solids, but the fact that the resin contents do not increase with increasing solids indicates that it is the increased viscosity that offsets the increased solids content.

TABLE 5. Preparation of solution-polymers and impregnation results

\begin{tabular}{|c|c|c|c|c|c|c|}
\hline $\begin{array}{l}\text { Run } \\
\text { num- } \\
\text { ber }\end{array}$ & $\begin{array}{l}\text { Monomer used with equal } \\
\text { volume of toluene as } \\
\text { solvent unless other- } \\
\text { wise noted }\end{array}$ & $\begin{array}{c}\text { Re- } \\
\text { flux } \\
\text { time }\end{array}$ & $\begin{array}{c}\text { A mount } \\
\text { catalyst }\end{array}$ & $\begin{array}{c}\text { Resin } \\
\text { solids of } \\
\text { solu- } \\
\text { tion- } \\
\text { poly- } \\
\text { mer }\end{array}$ & $\begin{array}{c}\text { Mean } \\
\text { resin } \\
\text { content } \\
\text { of three } \\
\text { treated } \\
\text { speci- } \\
\text { mens }\end{array}$ & $\begin{array}{l}\text { Mean } \\
\text { ratio of } \\
\text { resin } \\
\text { found } \\
\text { to resin } \\
\text { calcu- } \\
\text { lated for } \\
\text { three } \\
\text { speci- } \\
\text { mens }\end{array}$ \\
\hline \multirow{5}{*}{1} & \multirow{5}{*}{$n$-Butyl methacrylate.... } & Hours & \multirow{5}{*}{$\begin{array}{r}\text { Percent } \\
2.0\end{array}$} & Percent & Percent & Percent \\
\hline & & & & 37.5 & 18.6 & 100 \\
\hline & & 3 & & 39.5 & 19. 3 & 103 \\
\hline & & 20 & & 44.9 & 20.5 & 101 \\
\hline & & 44 & & 48.8 & 19.6 & 103 \\
\hline \multirow[t]{2}{*}{2} & & 1 & \multirow{2}{*}{0.2} & 24.3 & 10.3 & 88.4 \\
\hline & & 20 & & 43.8 & 4. 2 & 55.1 \\
\hline \multirow[t]{2}{*}{3} & _.... do . & 1 & \multirow{2}{*}{.5} & 29.4 & 12. 2 & 91.4 \\
\hline & & 20 & & 46.1 & 11.0 & 86.1 \\
\hline 4 & . do ${ }^{a} \ldots \ldots$ & 1 & 1. 0 & 35.5 & 17.1 & 101 \\
\hline 5 & Ethylacrylate & 1 & 0.5 & 46. 0 & 15. 1 & 83.2 \\
\hline 6 & - & 1 & 1. 0 & 46. 3 & 22.8 & 95.1 \\
\hline 7 & _._. do & 1 & 2. 0 & 50.0 & 23.1 & 93.4 \\
\hline 8 & Ethyl acrylate: & & & & & \\
\hline \multirow{5}{*}{9} & Unpressed specimens . & 1 & 0.2 & 41. 2 & 16. 2 & 74.4 \\
\hline & Pressed specimens & 1 & .2 & 41. 2 & 7.4 & 58.4 \\
\hline & Ethyl acrylate: & & & & & \\
\hline & Unpressed specimens_. & 1 & .5 & 45.0 & 23.6 & 94.3 \\
\hline & Pressed specimens & 1 & .5 & 45.0 & 16. 7 & 83.3 \\
\hline \multirow[t]{3}{*}{10} & Ethyl acrylate: & & & & & \\
\hline & Unpressed specimens & 1 & 1. 0 & 50.0 & 30.7 & 92.0 \\
\hline & Pressed specimens & 1 & 1.0 & 50.0 & 21.3 & 86.2 \\
\hline \multirow[t]{2}{*}{11} & $\begin{array}{l}\text { Ethyl acrylate: } \\
\text { Unpressed specimens. }\end{array}$ & 1 & 2. 0 & 50.0 & 28.0 & 95.3 \\
\hline & Pressed specimens & 1 & 2.0 & 50.0 & 19.4 & 89.3 \\
\hline 12 & $\begin{array}{l}\text { Ethyl acrylate, } n \text {-butyl } \\
\text { methacrylate }(50: 50)\end{array}$ & 1 & 1.0 & 40.1 & 16.3 & 99.5 \\
\hline \multirow[t]{2}{*}{13} & \multirow{2}{*}{$\begin{array}{l}\text { Ethyl acrylate, } n \text {-butyl } \\
\text { methacrylate }(20: 80)\end{array}$} & \multirow{2}{*}{1} & \multirow{2}{*}{1.0} & $\int \begin{array}{r}37.1 \\
\text { diluted }\end{array}$ & 20.4 & 80.0 \\
\hline & & & & {$\left[\begin{array}{c}\text { Cinuced } \\
50: 50\end{array}\right.$} & 12. 6 & 96.6 \\
\hline 14 & $\begin{array}{l}\text { Ethyl acrylate, } n \text {-butyl } \\
\text { methacrylate }(25: 75)\end{array}$ & 4 & 0.5 & \multirow[t]{2}{*}{37.6} & 16. 6 & 94.0 \\
\hline \multirow[t]{2}{*}{15} & Ethyl acrylate, $n$-butyl & & & & & \\
\hline & methacrylate $(25: 75)$ b & 4 & .5 & 31.3 & 15.4 & 96.1 \\
\hline
\end{tabular}

a Benzene solvent used.

b Ethyl acetate solvent used. Extra solvent necessary to keep resin dissolved.

Run 2 of table 5 shows that when using $0.2-$ percent catalyst instead of 2.0 percent as in run 1 , the molecular weight and viscosity are considerably increased so that only about half as much 
resin is absorbed, and the ratio of resin found to resin calculated is reduced from 100 to 88 percent.

Run 2 also illustrates the difference in results obtained by treating leather with a solutionpolymer of different solids content. Both the resin content of leather and the ratio of resin found to resin calculated are lower when treated with a solution-polymer of higher solids content. The reduction of both values points to increased viscosity directly or indirectly as an explanation for the lower resin content. Since Strain found that prolonged heating of polymethyl methacrylate solution-polymers decreases rather than increases molecular weight, then the lower resin content of leather corresponding to the higher solids content cannot be attributed to an increase in molecular weight during the 20-hour reflux period. The ratio of resin found to resin calculated corresponding to the higher solids content is only 55 percent, or about 30 percent less than for the solution-polymer of lower solids content. This wide difference in ratios suggests some preferential absorption of the solvent for the solution-polymer of higher solids content.

Runs 8 through 11 appear to show the effect of decreasing molecular weights with increasing catalyst concentration in a different way. Comparisons were made between leather specimens pressed at $3,000 \mathrm{lb} /$ in. $^{2}$ and unpressed specimens. The pressed specimens had a smaller volume, smaller pore size, and consequently less room for absorbing resin solution. It would be expected, therefore, that the resin content of the pressed specimens would be less than that for the unpressed. More important, however, is the apparent relation between catalyst concentration or molecular weight and the ratios of resin found to resin calculated. In the case of 0.2-percent catalyst, this ratio for the unpressed specimens is about 20 percent less than that for the other three resin solutions of this series (runs 9 through 11). In other words, a larger proportion of the resin solution pick-up consisted of solvent for the resin prepared with 0.2-percent catalyst, which tends to show that the molecular size for viscosity of this resin solution was too large for absorption. The ratios for the remaining three resins of this series are all about the same, which also tends to show that 0.5-percent catalyst produces a molecular size that is sufficiently small to allow very good absorption by the unpressed leather. This one- step difference in ratios for unpressed leather further tends to show that a molecular size smaller than that obtained with 0.5 -percent catalyst does not materially alter the ratios obtained.

The results obtained from specimens that were pressed at $3,000 \mathrm{lb} / \mathrm{in} .^{2}$ prior to treatment with the same solution-polymers suggest additional relations between the molecular size and viscosity, resin contents, and ratios of resin found to resin calculated. In the case of pressed specimens treated with resin prepared with 0.2-percent catalyst, only slightly more than half of the calculated resin was actually absorbed by the leather. As the catalyst concentration increases and the molecular weight of the resin decreases, the ratio differences between pressed and unpressed specimens exhibit two downward steps. These steps appear to indicate that as the molecular size and/or viscosity decreases, the large pore size of unpressed crust leather becomes less and less necessary for good absorption. It should also be pointed out that no substantial improvement in ratio differences was obtained for resins made with 2.0-percent catalyst as compared to 1.0 percent, as shown by the results of runs 10 and 11.

Run 13 illustrates the effect of diluting a somewhat viscous resin in order to obtain treated leather of different resin content. It will be noted that slightly more than half as much resin is obtained in leather when it is treated with a solution-polymer that has been diluted with an equal volume of solvent. This is explained on the basis of reduced viscosity. The solutionpolymer was diluted with an equal volume of toluene. The resin content obtained, however, was slightly more than half that obtained for the undiluted solution-polymer. A suggested explanation for this deviation from proportionality is based on reduced viscosity, and a higher proportion of solution solids absorbed by leather treated with the diluted solutions, as shown by the values for the ratios of resin found to resin calculated. It is apparent, therefore, that the resin content of treated leather may be varied at will to any value lower than that obtained with undiluted solution-polymer, although the actual value of resin content obtained with the diluted solution may not be predicted precisely from the extent of dilution.

Similar relations and effects may be observed in 
the remaining data of table 5 , which have not been discussed in detail. It should be remembered, of course, that when prepared under corresponding conditions, polyethyl acrylate is softer and its solutions less viscous than polybutyl methacrylate. As would be expected, copolymers will have properties intermediate between those of the separately prepared polymers.

\section{(b) Solutions of Resins of Known Molecular Weights}

In order to have some definite reference points from which to judge the effects of molecular weight variations on resin impregnating solutions, polymethyl methacrylates of known molecular weights were used for treatment, as indicated in table 6 . The impregnations were carried out in the same way as those described above for specially prepared solution-polymers. Viscosities of the solutions increased with molecular weight, as would be expected. A resin of corresponding molecular weight but softer and less viscous would probably be absorbed better than polymethyl methacrylate. However, these polymethyl methacrylate solutions do demonstrate the same relations between molecular weight and resin content of treated leather, as discussed under specially prepared solution-polymers. Table 6 shows that when polymethyl methacrylate is used, as described above, and has a molecular weight of 11,000 or 16,000 , about 14 percent of resin is absorbed. However, for a polymer with a molecular weight of 43,000 , only about one-tenth as much resin is absorbed. The use of methanol indicates that it is only slightly helpful in reducing viscosity and increasing resin content.

TABLE 6. Impregnation with polymethyl methacrylate resins of known molecular weight

\begin{tabular}{|c|c|c|c|c|}
\hline $\begin{array}{l}\text { Molecular weight } \\
\text { of resin }\end{array}$ & Solvent & $\begin{array}{l}\text { Resin } \\
\text { solids }\end{array}$ & $\begin{array}{l}\text { Mean } \\
\text { resin } \\
\text { content } \\
\text { of three } \\
\text { treated } \\
\text { speci- } \\
\text { mens }\end{array}$ & $\begin{array}{l}\text { Ratio of } \\
\text { resin } \\
\text { found to } \\
\text { resin cal- } \\
\text { culated } \\
\text { for three } \\
\text { speci- } \\
\text { mens }\end{array}$ \\
\hline $11,000 \ldots$ & Toluene _... & $\begin{array}{c}\text { Percent } \\
20\end{array}$ & $\begin{array}{c}\text { Percent } \\
15.3\end{array}$ & $\begin{array}{r}\text { Percent } \\
110\end{array}$ \\
\hline $16,000 \ldots$ & _.... do do _......... & 20 & 13.6 & 107 \\
\hline $43,000 \ldots .$. & do do & 20 & 1.4 & 30 \\
\hline $43,000 \ldots$ & Toluene-methanol (3:1) $\ldots$ & 20 & 2. 4 & 47 \\
\hline
\end{tabular}

\section{Immersion in Thiokol LP-2 Followed by Special Cures}

Another type of resin solution that has promise for treating sole and shoe upper leathers is a polysulfide rubber dissolved in toluene. The Thiokol Corporation has made exploratory treatments of leather specimens with Thiokol LP-2. In considering the test data that follow, it should be recalled that these experiments are preliminary ones and do not represent any development work whatever. The processing appears to be simple and after the elimination of certain difficulties, should lend itself to easy commercial application.

Essentially, the method depends upon impregnating the leather specimens with a low molecular weight resin solution, by immersing, wiping off the excess solution, and curing or further polymerizing in situ. For shoe uppers and other soft leathers, a "chain-terminator" is used to maintain a relatively low molecular weight and soft resin, which does not materially reduce flexibility.

Treated vegetable-tanned crust leather contained 34-percent Thiokol LP-2; factory finished taps, 18 percent; and degreased Army retanned upper leather, 50 percent. Contrary to previous experience, treatment with Thiokol LP-2, as described, contributes practically no odor to the leather specimens.

\section{Properties of Treated Leathers}

Comparative tests were made on different types of treated and untreated leathers. The tests included abrasion, water absorption, water-vapor permeability, and relative stiffness.

All tests were carried out in accordance with Federal Specification KK-L-311, Leather and Leather Products; General Specifications (Methods of Sampling, Inspection, and Tests).

\section{Abrasion Resistance}

Results of abrasion tests are shown in figures 2 , 3 , and 4 . Figure 2 shows comparative results of vegetable-tanned crust leather that was treated with solutions containing equal amounts by volume of the monomers indicated and neatsfoot oil followed by polymerization in situ. The improvement shown by extrapolating the curve for polybutyl methacrylate to the line corresponding to 60 -percent abrasion loss is about 75 percent, 


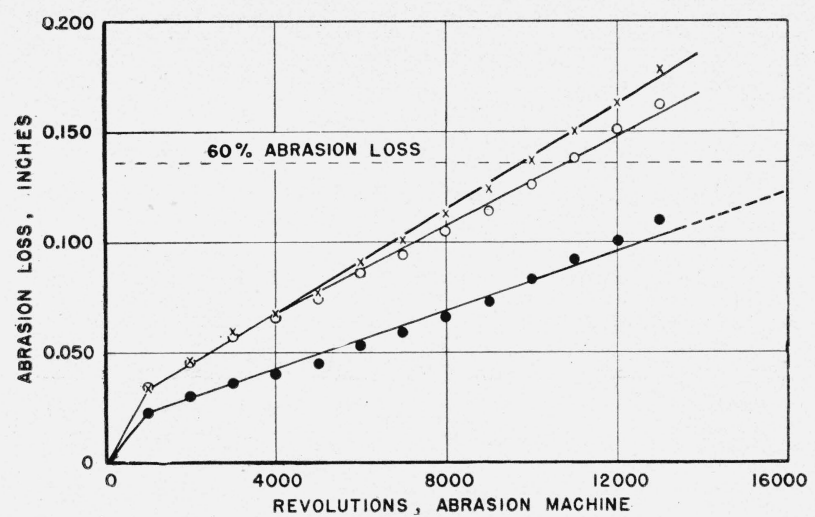

Figure 2. Effect of polybutyl methacrylate and polyethyl acrylate (polymerized in situ) on abrasion resistance of vegetable-tanned crust leather.

Mean values of four specimens for each treatment plotted. methacrylate $(20.10 \%) ; \bigcirc$, ethyl acrylate $(8.4 \%) ; \times$, untreated.

and about 10-percent improvement for polyethyl acrylate. This wide difference in abrasion improvement is probably due to the fact that polyethyl acrylate is much softer than polybutyl methacrylate, and also because there was only 8 percent of the former resin in the treated leather compared to 20 percent for the latter resin. Figure 3 shows that the improvement found was not due to the neatsfoot oil. Figure 4 shows the improvement in abrasion resistance due to Thiokol treatment of factory-finished sole leather. The improvement of specimens treated with Thiokol LP-2 is about 30 percent. Attention is drawn to the fact that for all the curves the points are quite close to a straight line. Indirectly this linearity

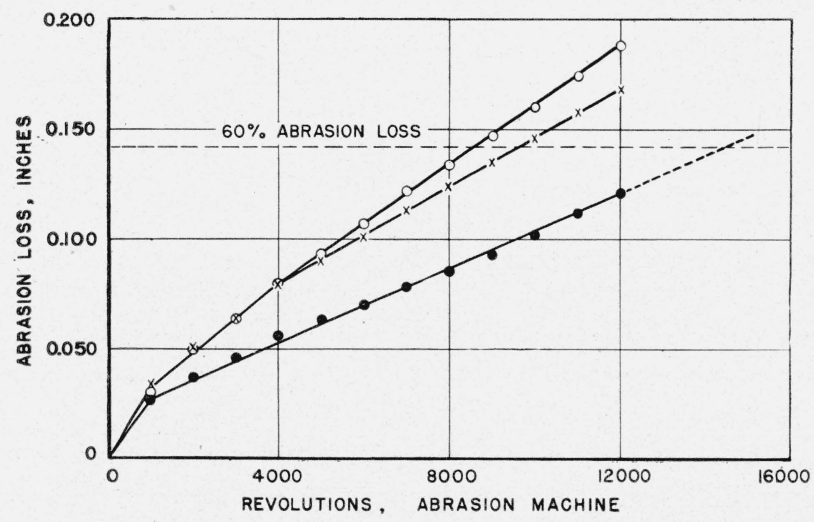

Figure 3. Effect of polybutyl methacrylate (polymerized in situ) and neatsfoot oil on abrasion resistance of vegetable-tanned crust leather.

Mean values of four specimens for each treatment plotted. Butyl methacrylate $(29.7 \%) ; \bigcirc$, neatsfoot oil; $\times$, untreated.

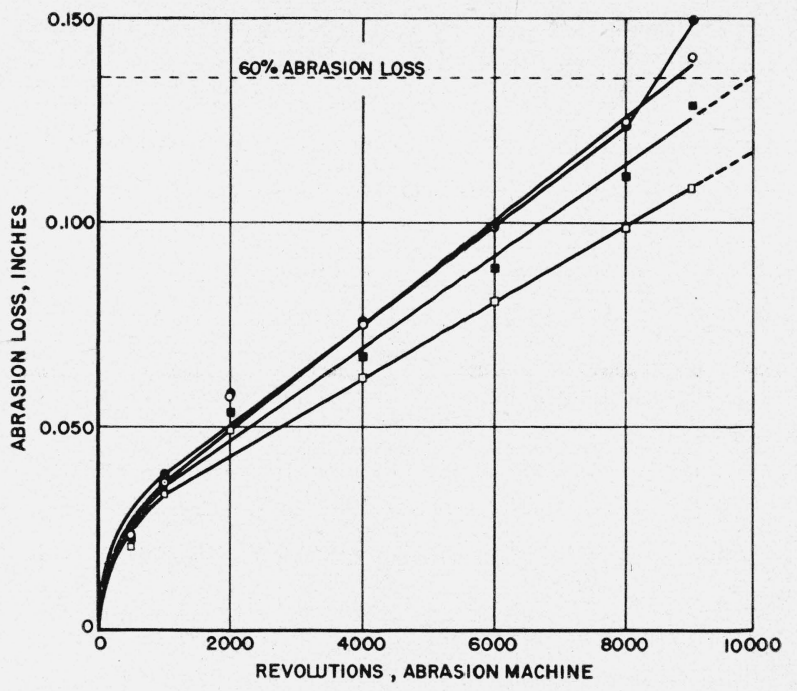

Figure 4. Effect of treatment with Thiokol LP-2 on abrasion resistance of factory finished sole leather

Mean values of three specimens for each treatment plotted.P, Factory finished; $\bigcirc$, leached, factory finished; $\mathbf{D}$, Thiokol treated, factory finished; $\square$, leached, Thiokol treated, factory-finished.

implies that penetration of the resins is more or less uniform throughout. Uniform penetration is to be expected for leather treated with monomer and subsequently polymerized, as the monomer has about the same viscosity as kerosine. The linear abrasion curves for soles treated with Thiokol LP-2 indicate uniform penetration, thereby showing that the molecular weight is suitable for adequate penetration.

Abrasion tests on leather treated with solutionpolymers of specially prepared polyacrylates, polybutyl methacrylates, or copolymers thereof do not show any improvement in abrasion resistance over that of untreated leather. This difference from the improved abrasion resistance shown by the same polymerized monomers by the in situ method, suggests that in the latter process a higher degree of polymerization has occurred so as to impart greater abrasion resistance to treated leather.

\section{Water Absorption}

Curves for water absorption are shown in figures $5,6,7$, and 8 . The resins in the specimens shown in figure 5 were polymerized in situ. The curves for polybutyl methacrylate and copolymer of butyl methacrylate and ethyl acrylate practically coincide. The relative position of the curves for these two resin treatments of vegetable crust leather clearly establishes the superior 


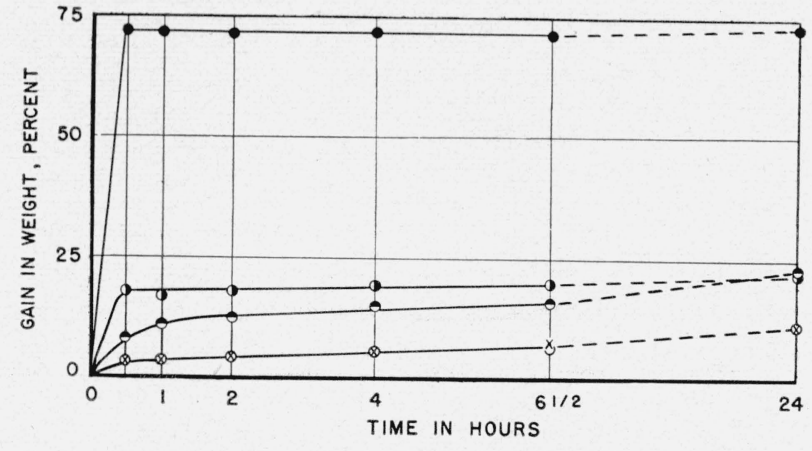

Figure 5. Effect of resins (polymerized in situ) indicated on water absorption of vegetable-tanned crust leather

Mean values of four specimens for each treatment plotted. Controls; $\odot$, ethyl acrylate $(40.6 \%) ; \times$, butyl methacrylate $(43.3 \%)$; , ethyl acrylateneatsfoot oil $(21.0 \% \mathrm{R}, 22.0 \% \mathrm{O})$; $\bigcirc$, butyl methacrylate-ethyl acrylate (copolymer) $(46.0 \%)$.

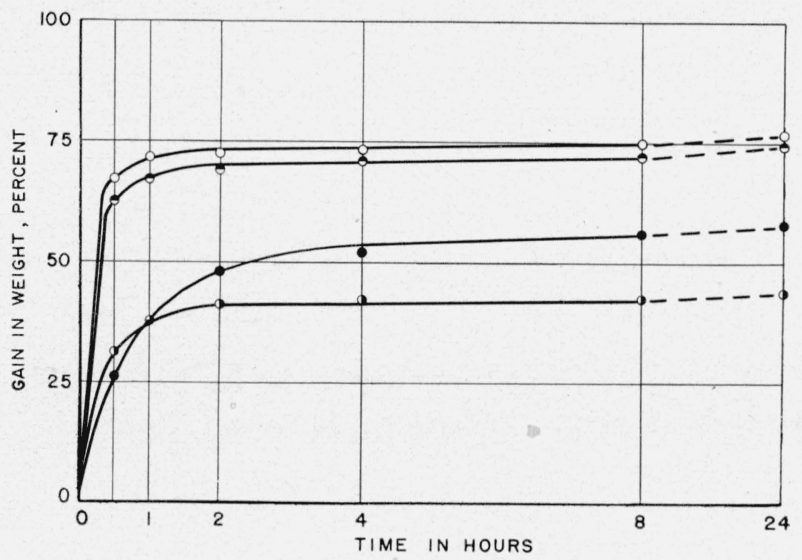

Figure 6. Effect of solution-polymer resins on water absorption of vegetable-tanned crust leather.

Mean values of four specimens for each treatment plotted. $O$, Controls; $\boldsymbol{\Theta}$, polyethyl acrylate $(6.8 \%) ; \boldsymbol{O}$, polyethyl acrylate $(15.9 \%)$;, polybutyl methacrylate $(8.3 \%)$.

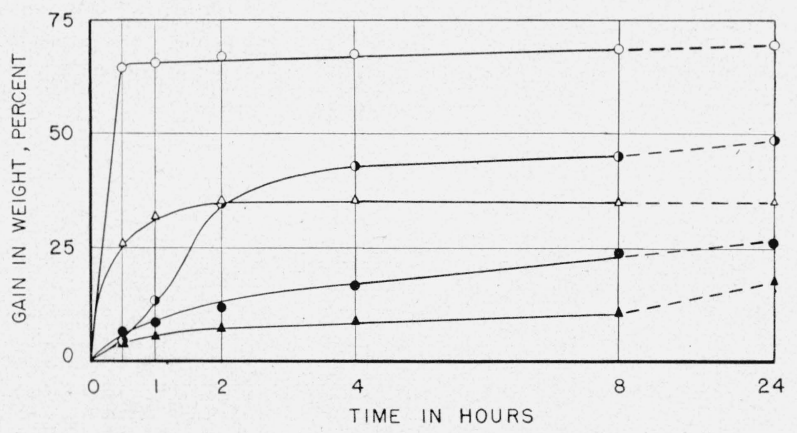

Figure 7. Effect of different resins on water absorption of vegetable-tanned crust and factory finished sole leather.

Mean values of two specimens for each treatment plotted. $O$, Vegetable crust (controls); $\mathbf{C}$, vegetable crust (copolymer, $10 \%$ ); $\triangle$, factory finish (controls); $\boldsymbol{\bullet}$, vegetable crust (Thiokol, $34 \%$ ); $\mathbf{\Delta}$, factory finish (Thiokol, $18 \%$ ).

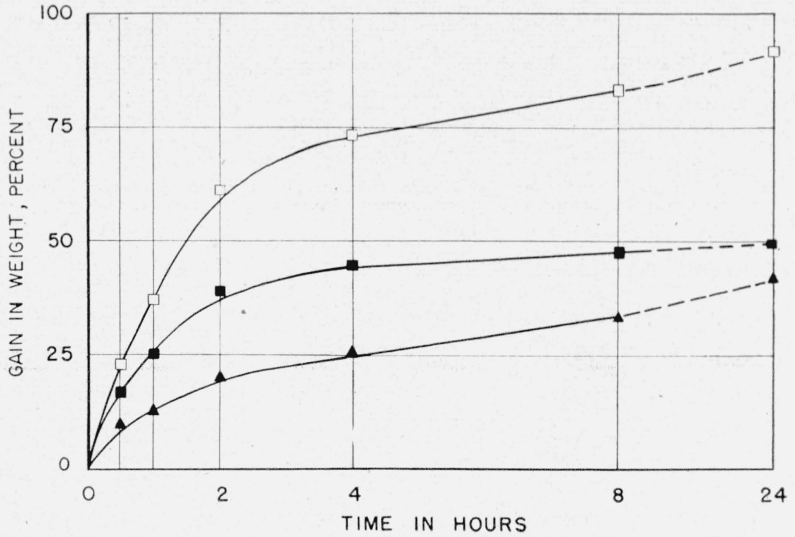

Figure 8. Effect of different resins on water absorption of degreased chrome retan upper leather.

Mean values of two specimens for each treatment plotted. $\square$, Degreased chrome retan (controls), $\mathbf{\square}$, degreased chrome retan (Thiokol, 50\%); degreased chrome retan (polyethylacrylate, $50 \%$ ).

resistance to water absorption by polybutyl methacrylate even when copolymerized with ethyl acrylate in equal amounts. The ethyl acrylate and ethyl acrylate-neatsfoot oil treatments have curves that are similar in general shape. However, the water absorption curve for ethyl acrylate is generally better than for the resin-oil treatment, and especially better for the $1 / 2$-hour period.

Figure 6 illustrates the effect of treating vegetable-tanned crust leather with solution-polymers. It will be noted that polybutyl methacrylate is about five times as effective in decreasing resistance to water absorption as polyethyl acrylate for approximately the same resin contents. Compared to the curves in figure 4 , it will be observed that the reductions in water absorption are much less, as are the amounts of resin in the treated specimens. The $1 / 2-\mathrm{hr}$ absorption value for ethyl acrylate-neatsfoot oil (12 percent of resin and 22 percent of oil) in figure 4 is the highest of the treated specimens, and yet it is only about twothirds the value of that obtained for 16 percent polyethyl acrylate solution-polymer. The more favorable results may be partially due to the neatsfoot oil or to a presumably higher degree of polymerization by the in situ process.

Figure 7 shows the effects of different solutionpolymers and Thiokol LP-2 on vegetable-tanned crust leather and factory-finished sole leather. The $1 / 2$-hr absorption values for vegetable-tanned crust leather treated with $n$-butyl methacrylateethyl acrylate solution-eopolymer and Thiokol LP-2 are shown to be about the same. However, 
as time increases to 24 hours, the specimens treated with Thiokol LP-2 absorbed only about half as much as those treated with the acrylate solution-copolymer. A substantial part of this difference in absorptions for longer periods may be due to the fact that there was 34 percent of Thiokol LP-2 in the leather but only 10 percent of the copolymer. From a service viewpoint, the 1/2-hr absorption values are probably more significant than the 24-hr values. Factory-finished sole leather treated with Thiokol LP-2 has the most favorable absorption curve.

Figure 8 shows the effect of different resin treatments on degreased chrome-retanned upper leather. The $1 / 2-\mathrm{hr}$ absorption value for polyethyl acrylate is approximately two-thirds that of specimens treated with Thiokol LP-2. There was approximately 50 percent of resin in both sets of treated specimens, so that direct comparisons as to the effectiveness of the two treatments are valid.

\section{Water-Vapor Permeability}

Water-vapor permeability data on vegetabletanned crust leather (table 7 ) show that 8.3 percent of polybutyl methacrylate and 15.6 percent of polyethyl acrylate both reduce the permeability from 567 to about $325\left(\mathrm{~g} / \mathrm{m}^{2}\right) / 24 \mathrm{hr}$. Seven percent of polyethyl acrylate reduces permeability by an intermediate amount; i. e., $480\left(\mathrm{~g} / \mathrm{m}^{2}\right) / 24 \mathrm{hr}$. The last three items of table 7 show degreased chrome retanned upper leather treated with polyethyl acrylate and Thiokol LP-2; both decrease water vapor permeability by about the same amount, i. e., to about $400\left(\mathrm{~g} / \mathrm{m}^{2}\right) / 24 \mathrm{hr}$. This value is considered to be ample for shoe upper leather.

TABLE 7. Physical tests on treated and untreated leathers

\begin{tabular}{|c|c|c|c|c|c|c|}
\hline \multirow{2}{*}{ Type of leather } & \multirow{2}{*}{ Treatment } & \multirow{2}{*}{$\begin{array}{l}\text { Mean } \\
\text { resin con- } \\
\text { tent of } \\
\text { four } \\
\text { specimens }\end{array}$} & \multicolumn{2}{|c|}{$\begin{array}{l}\text { Mean water absorp- } \\
\text { tion of four speci- } \\
\text { mens for- }\end{array}$} & \multirow{2}{*}{$\begin{array}{l}\text { Mean } \\
\text { water } \\
\text { vapor } \\
\text { permea- } \\
\text { bility of } \\
\text { four } \\
\text { specimens }\end{array}$} & \multirow{2}{*}{$\begin{array}{l}\text { Mean } \\
\text { relative } \\
\text { stiffness } \\
\text { factor of } \\
\text { four } \\
\text { specimens }\end{array}$} \\
\hline & & & $1 / 2 \mathrm{hr}$ & $24 \mathrm{hr}$ & & \\
\hline Veretable crust & Fthrl orroto a & Percent & Percent & Percent & $\left(g / m^{2}\right) / 24 h r$ & $E$ \\
\hline $\begin{array}{l}\text { vegetane crust. } \\
\text { Do }\end{array}$ & Ethyl acrylate-Neatsfoot a & $\begin{array}{l}40.0 \\
12.0\end{array}$ & $\begin{array}{r}0.2 \\
18.0\end{array}$ & $\begin{array}{l}22.9 \\
22.2\end{array}$ & (n....... & ........ \\
\hline Do & Ethyl acrylate-Butyl methacrylate a & 46.0 & 3.4 & 11.2 & (n............ & (n............. \\
\hline Do & Butyl methacrylate a & 43.3 & 3.5 & 11.2 & ....... & .......... \\
\hline Do ........ & None & 0.0 & 71. 7 & 72.8 & ........ & -...... \\
\hline Do_... & Ethyl acrylate solution-polymer.-.. & 15. 9 & 31. 2 & 43.8 & 316 & 14.5 \\
\hline Do & do & 6.8 & 62.5 & 74.3 & 480 & 20.1 \\
\hline Do & 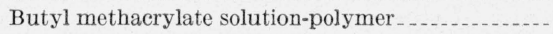 & 8.3 & 26. 0 & 58.0 & 331 & 45. 7 \\
\hline Do & None & 0.0 & 67.1 & 76.6 & 567 & 18.1 \\
\hline Factory finished vegetable-tanned.... & _. do & .0 & b 25.7 & b 35.3 & & - n \\
\hline Do & Thiokol LP-2 solution & b 17.6 & b 4.1 & b 18.8 & -....... & ........ \\
\hline Vegetable crust.................... & None & 0.0 & b 64.6 & b 69.3 & ....... & b 7.5 \\
\hline Do & Thiokol LP-2 solution & b 34.1 & b 6.6 & b 26.4 & -...... & b 23.2 \\
\hline Do & $\begin{array}{l}\text { Ethyl acrylate-Butyl methacrylate copolymer solu- } \\
\text { tion-polymer. }\end{array}$ & b 10.4 & b 4.4 & b 48.6 & (n........ & (n......... \\
\hline Degreased chrome retan upper.... & None & 0.0 & b 22.9 & b 91.4 & b 1,011 & b 4.9 \\
\hline Do & Thiokol LP-2 solution & b 50.1 & b 16.7 & b 49.3 & b 408 & b 3.7 \\
\hline Do & Ethyl acrylate solution-polymer & b 49.5 & b 9.5 & b 42.1 & b 394 & b 3.3 \\
\hline
\end{tabular}

a Polymerized in situ.

bMean of two specimens.

\section{Relative Stiffness}

The relative stiffness factors of several leathers and treatments are shown in table 8 . It will be noted that 16-percent polyethyl acrylate has practically no influence on stiffness of vegetable-tanned crust leather, whereas 8 percent of polybutyl methacrylate more than doubles the stiffness factor. Table 7 shows that treatment with Thiokol LP-2 triples the stiffness factor of vegetabletanned crust leather. However, degreased chrome retan upper leather shows no appreciable change in stiffness when treated with soft acrylate or Thiokol LP-2 resins. 


\section{Summary}

1. A laboratory procedure is described for polymerizing acrylate monomers in situ. By use of small polymerization chambers, as much as 50percent resin can be obtained in vegetable-tanned crust leather.

2. Specially prepared solution polymers have been made to impregnate leather. Up to 25-percent resin has been obtained in vegetable-tanned crust, and 50 percent in chrome retanned upper leather by this procedure.

3. Treatment with Thiokol LP-2 can be controlled to give a very stiff sole or to produce a soft shoe upper leather.

4. Abrasion resistance of vegetable-tanned crust leather is improved about 75 percent by $n$-butyl methacrylate polymerized in situ. Treatment with Thiokol LP-2 improves abrasion resistance by about 30 percent, whereas solution-copolymers of $n$-butyl methacrylate and ethyl acrylate contributed no improvement.

5. Half-hour water absorption data on vegetabletanned crust leather indicate that treatment with $n$-butyl methacrylate, polymerized in situ, shows 95-percent reduction over untreated leather. On the same basis, solution-copolymers of $n$-butyl methacrylate and ethyl acrylate as well as Thiokol LP-2 are all about equally effective. For degreased chrome-retan leather, polyethyl acrylate solution polymer reduces $1 / 2$-hr water absorption about one-half, and Thiokol LP-2 reduces $1 / 2-\mathrm{hr}$ water absorption about one-third.

6. Water vapor permeability of degreased chrome-retan upper leather is reduced by 60 percent. However, the reduced value of about 400 $\mathrm{g} / \mathrm{m}^{2} / 24 \mathrm{hr}$ is considered ample for comfort.

7. Stiffness of vegetable-tanned crust leather treated with $n$-butyl methacrylate polymerized in situ is not appreciably different from untreated leather. Vegetable-tanned crust leather treated with Thiokol LP-2 has a stiffness factor somewhat more than double that of untreated leather. Degreased chrome-retan upper leather shows no appreciable change in flexibility when treated with soft acrylate or Thiokol LP-2 resin. However, a different cure for Thiokol LP-2 in treated chrome retan upper leather reduces the stiffness slightly, as does polyethyl acrylate solution-polymer.

\section{References}

[1] J. C. Niedercorn and F. D. Thayer, J. Am. Leather Chem. Assoc. 40, 242 (1945).

[2] E. Chadwick, J. Intern. Soc. Leather Trades Chem. 30, 53 (1946).

[3] George Virtue, U. S. Patent 2,413,806 (1947).

[4] D. E. Strain, R. G. Kennelley, and H. R. Dittmar, Ind. Eng. Chem. 31, 382 (1939).

[5] Carl E. Barnes, J. Am. Chem. Soc. 6\%, 217 (1945).

[6] Claus Heuck, Modern Plastics 24, 158 (1946).

[7] I. M. Kolthoff, J. Am. Chem. Soc. 69, 441, 2143 (1947).

[8] D. E. Strain, Ind. Eng. Chem. 30, 345 (1938).

Washington, July 30, 1948. 